\title{
KOMISI PEMBERANTASAN KORUPSI DALAM KONSTRUKSI MEDIA ONLINE (ANALISIS WACANA KRITIS BERITA PUTUSAN SIDANG PRAPERADILAN PERTAMA SETYA NOVANTO DI TRIBUNNEWS.COM PERIODE 30 SEPTEMBER 2017)
}

\author{
Indah Suryawati, Muhammad Syaid Agustiar \\ Fakultas IImu Komunikasi, Universitas Budi Luhur, Jakarta \\ indahsuryawati_2121@yahoo.com, agustiar1988@yahoo.com
}

\begin{abstract}
Abstrak
Komisi Pemberantasan Korupsi (KPK) merupakan lembaga negara yang bersifat independen yang melaksanakan tugas dan wewenangnya bebas dari kekuasaan manapun. Penelitian ini bertujuan pertama, membongkar konstruksi wacana KPK dalam berita pasca sidang putusan praperadilan pertama Setnov periode 30 September 2017 di Tribunnews.com, dan kedua, mengkaji faktor-faktor dibalik konstruksi Tribunnews.com tentang wacana KPK. Metode penelitian yang digunakan adalah Analisis Wacana Kritis Norman Fairclough. Adapun metode yang digunakan untuk tingkat pertama adalah metode framing. Tingkat kedua adalah pemahaman teks dan konteks. Ada lima langkah yang dijadikan acuan. Pertama, fokus kepada ketidakberesan sosial dalam aspeksemiotikanya. Kedua, mengidentifikasi hambatan-hambatan untuk menangani aspek ketidakberesan sosial tersebut. Ketiga, mempertimbangkan apakah tatanan sosial membutuhkan ketidakberesan sosial itu. Keempat, mengidentifikasi cara-cara yang mungkin untuk mengatasi hambatan tersebut. Kelima, melakukan refleksi secara kritis dari keempat poin tersebut. Hasil penelitian menunjukkan bahwa Tribunnews.com meletakkan KPK sebagai pihak yang salah. Setnov yang benar. KPK dikonstruksikan tidak memiliki kompetensi untuk menangani kasus Setnov. Tribunnews.com mengarahkan pandangan khalayak untuk menyudutkan KPK. Pihak Tribunnews.com melawan arus suara publik dalam pemberitaannya tentang KPK adalah sebagai strategi bisnis. Positioning Tribunnews.com ini dilakukan karena nyaris semua media online berada untuk membela KPK. Dari sudut pandang bisnis media hal ini tidak menguntungkan untuk mencari iklan.
\end{abstract}

Kata Kunci : Konstruksi, Wacana Kritis, Berita Sidang, Komisi Pemberantasan Korupsi

\begin{abstract}
The Corruption Eradication Commission is a state institution that is independent and in carrying out its duties and authority free from any power. This study aims at first, dismantling the construction of KPK discourse in the post-trial news of the first pre-trial ruling of Setnov for September 30, 2017 at Tribunnews.com, and secondly reviewing the factors behind Tribunnews. com construction of the KPK discourse. The research method used is Critical Discourse Analysis of Norman Fairclough. The method used for the first level is the framing method. The second level is the understanding of text and context. There are five steps that are used as a reference. First, focus on social irregularities in its semiotic aspects. Second, identify barriers to address the social irregularities. Third, consider whether social order requires social irregularity. Fourth, identify possible ways to overcome these obstacles. Fifth, reflect critically from those four points. The results showed that Tribunnews.com put the KPK as the wrong party. Means that Setnov is
\end{abstract}


the right one. KPK was constructed with no competence to handle Setnov's case. Tribunnews. com directs the public view to cornering the KPK. Tribunnews.com parties against the current public voice in its coverage of the KPK is a business strategy. Positioning Tribunnews.com is done because almost all online media are to defend the Commission. From a media business point of view it is not profitable to find ads.

\section{Keywords: Construction, Critical Discourse, News Session, Corruption Eradication Commission}

\section{Pendahuluan}

Sepak terjang Komisi Pemberantasan Korupsi (KPK) sebagai lembaga independen memang tidak diragukan lagi. Santer menghiasi media massa menjadi salah satu bukti tapak tilas dalam memerangi kasus-kasus korupsi di Indonesia. Lembaga ini memang diberi amanat melakukan pemberantasan korupsi secara profesional, intensif, dan berkesinambungan.

Dibentuk pada masa kepemimpinan Susilo Bambang Yudoyono sebagai presiden dan kemudian diperkuat oleh Undang-Undang Nomor 30 Tahun 2002 tentang Komisi Pemberantasan Tindak Pidana Korupsi. Dalam pelaksanaan tugasnya, KPK berpedoman kepada lima asas, yaitu kepastian hukum, keterbukaan, akuntabilitas, kepentingan umum, dan proporsionalitas. KPK bertanggung jawab kepada publik dan menyampaikan laporannya secara terbuka dan berkala kepada Presiden, DPR, dan BPK (https://www.kpk.go.id/id/tentang-kpk/sekilas-kpk, diakses pada 27 November 2018, pukul 23:04 WIB).

Pembentukan KPK bukan untuk mengambil alih tugas pemberantasan korupsi dari lembaga-lembaga yang ada sebelumnya. Penjelasan undang-undang menyebutkan peran KPK sebagai trigger mechanism, yang berarti mendorong atau sebagai stimulus agar upaya pemberantasan korupsi oleh lembaga-lembaga yang telah ada sebelumnya menjadi lebih efektif dan efisien. Adapun tugas KPK adalah: koordinasi dengan instansi yang berwenang melakukan pemberantasan tindak pidana korupsi (TPK); supervisi terhadap instansi yang berwenang melakukan pemberantasan TPK; melakukan penyelidikan, penyidikan, dan penuntutan terhadap TPK; melakukan tindakan-tindakan pencegahan TPK; dan melakukan monitor terhadap penyelenggaraan pemerintahan negara (https://www.kpk.go.id/id/tentangkpk/sekilas-kpk).

Kasus korupsi yang melibatkan Setya Novanto (Setnov) sungguh menarik perhatian masyarakat. Setelah sidang putusan praperadilan yang dimenangkan oleh Setnov, masyarakat pun melakukan gerakan sosial melalui twitter dengan membuat tagar \#ThePowerOfSetnov. Antusiasme masyarakat yang tinggi menyangkut kasus korupsi e-KTP hingga digelarnya sidang praperadilan kedua Setnov, membuat media terus menerus mengangkat berita tersebut

Namun dibalik ramainya pemberitaan mengenai kasus e-KTP Setnov, peneliti ingin fokus meneliti bagaimana wacana media tentang KPK terkait pasca sidang putusan praperadilan 
pertama Setnov. Berdasarkan alexa.com yang diakses pada 30 November 2017, dari 10 ranking web teratas, peneliti memilih Tribunnews.com yang berada di peringkat keempat. Alasan memilih portal berita ini karena Tribunnews.com memproduksi lebih banyak berita pasca putusan sidang praperadilan pertama Setnov dibanding portal berita lain yaitu sebanyak 27 berita.

Peneliti menandai dalam beberapa headline periode 30 September 2017, Tribunnews. com sudah memberi label pada KPK antara lain KPK "kurang cermat", KPK "pantas kalah", KPK "diminta tobat", KPK "introspeksi", KPK "tidak bisa keluarkan sprindik baru Setya Novanto", dan KPK "tidak teliti". Sedangkan portal berita lainnya seperti Detik.com, Liputan6.com, dan lainnya tidak melakukan hal tersebut pada headline berita mereka pada periode yang sama.

Pemilihan headline, tema, kalimat, dan kata dalam sebuah berita yang disajikan media tersebut kepada khalayak sepenuhnya tidak bebas nilai. Kebijakan resmi redaksi terhadap suatu peristiwa bukan hanya tertuang dalam editorial atau tajuk rencana, tetapi juga pada pemilihan headline untuk menentukan arah berita. Oleh karena itu, pemilihan kosa kata dalam headline misalnya, bisa saja merepresentasikan bagaimana wartawan mengkonstruksi realitas dalam sebuah berita. Tentunya dengan cara dan sudut pandang yang berbeda, tentang siapa dan angle apa yang ingin ditonjolkan dan dianggap penting oleh media itu sendiri.

Ini menunjukkan bahwa setiap media memiliki kepentingannya masing-masing dalam memilih suatu peristiwa yang akan mereka beritakan. Media akan memutuskan seberapa dalam mereka akan memberitakan suatu peristiwa; apakah hanya akan memberitakan peristiwa tertentu demi kepentingan aktualitas semata, atau memberitakan secara mendalam dan terus menerus demi kepentingan ideologinya, atau bahkan ada kepentingan ekonomi hingga politik yang menjadi tujuan diproduksinya berita tersebut.

Menurut Ibnu Hamad, realitas dalam media massa bukanlah realitas yang sebenarnya (Hamad, 2004: 3). Tak heran jika kalangan kritis beranggapan bahwa berita bukanlah sekedar subyektivitas dari si pembuat berita, melainkan ada suatu kekuatan dominan yang mempengaruhi konstruksinya. Ternyata media bukanlah entitas yang netral, tetapi bisa dikuasai oleh kelompok dominan (Eriyanto, 2012: 23). Karena itu, peneliti tertarik untuk menggunakan Analisis Wacana Kritis untuk membongkar konstruksi wacana KPK dalam berita pasca sidang putusan praperadilan pertama Setya Novanto periode 30 September 2017 di Tribunnews.com. Selain itu, peneliti tertarik untuk mengkaji faktor-faktor dibalik konstruksi Tribunnews.com tentang wacana KPK.

Analisis Wacana Kritis (AWK) mencoba untuk membongkar yang salah atau tidak beres di masyarakat, seperti adanya ketidakadilan, ketaksetaraan, pembatasan kebebasan atau diskriminasi (Haryatmoko, 2016:vi). Agar AWK semakin tajam, orang perlu menganalisis pula hubungan dengan luar teks yang meliputi . Analisis ini membahas bagaimana unsur lain secara intertekstual terkait dengan teks; dan bagaimana suara-suara lain termuat dalam teks; 
akhirnya, bagaimana teks lain disinggung, diasumsikan, atau didialogkan. Intertekstualitas ini bisa tampak dalam dua bentuk: pertama, kehadiran unsur-unsur dari teks lain dalam suatu teks yang bisa berupa kutipan, acuan, atau isi; kedua, dalam laporan pembicaraan, tulisan atau pikiran, bukan hanya kutipan yang kita jumpai, namun bisa juga ringkasan. Maka teks selalu memiliki asumsi (Haryatmoko, 2016:18).

Dalam penelitian ini, peneliti menggunakan Analisis Wacana Kritis Model Norman Fairclough. Model Fairclough didasarkan pada sebuah pertanyaan, yaitu bagaimana menghubungkan teks yang mikro dengan konteks masyarakat yang makro. Titik utamanya adalah melihat bahasa sebagai praktik kekuasaan. Oleh karena itu, Analisis Wacana Kritis Model Norman Fairclough harus dipusatkan pada bagaimana bahasa itu terbentuk dan dibentuk dari relasi sosial dan konteks sosial tertentu.

Faiclough melihat teks dalam berbagai tingkatan. Sebuah teks bukan hanya menampilkan bagaimana suatu obyek digambarkan tetapi juga bagaimana hubungan antarobyek didefinisikan. Ada tiga elemen dasar dalam model Fairclough, yang dapat digambarkan ke dalam tabel berikut (Eriyanto, 2012: 289).

Tabel 1

Analisis Teks

\begin{tabular}{|c|l|}
\hline \multicolumn{1}{|c|}{ UNSUR } & \multicolumn{1}{|c|}{ YANG INGIN DILIHAT } \\
\hline Representasi & $\begin{array}{l}\text { Bagaimana peristiwa, orang, kelompok, situasi, keadaan, } \\
\text { atau apapun ditampilkan dan digambarkan dalam teks. }\end{array}$ \\
\hline Relasi & $\begin{array}{l}\text { Bagaimana hubungan antara wartawan, khalayak, dan } \\
\text { partisipan berita ditampilkan dan digambarkan dalam } \\
\text { teks. }\end{array}$ \\
\hline Identitas & $\begin{array}{l}\text { Bagaimana identitas wartawan, khalayak, dan partisipan } \\
\text { berita ditampilkan dan digambarkan dalam teks. }\end{array}$ \\
\hline
\end{tabular}

Sumber : Model Norman Fairclough (Eriyanto, 2012: 289)

Melalui dimensi teks, akan terlihat bagaimana isu tersebut digambarkan dalam teks beritanya, lalu akan terlihat juga bagaimana hubungan antara wartawan yang membuat beritanya dan masyarakat yang membacanya, serta akan terlihat juga bagaimana identitas wartawan dan masyarakat yang tergambar dalam berita tersebut.

Fairclough menawarkan empat langkah metode AWK (N.Fairclough, 2010:235). Pertama, memfokuskan pada suatu 'ketidakberesan sosial', dalam aspek semiotiknya. Kedua, mengidentifikasi hambatan-hambatan untuk menangani 'ketidakberesan sosial' itu. Ketiga, 
mempertimbangkan apakah tatanan sosial itu 'membutuhkan' ketidakberesan sosial tersebut. Keempat, mengidentifikasi cara-cara yang mungkin untuk mengatasi hambatan-hambatan itu.

\section{Tujuan Penelitian}

Peneliti ingin mengetahui Analisis Wacana Kritis Model Norman Fairclough pada pemberitaan Komisi Pemberantasan Korupsi dalam pasca sidang putusan praperadilan pertama Setya Novanto di Media Online Tribbunnews.com periode 30 September 2017.

\section{Kerangka Teori}

Analisis wacana sering dikaitkan dengan praktik pemakaian bahasa. Menurut pandangan kritis, analisis wacana tidak dipusatkan pada kebenaran atau ketidakbenaran struktur tata bahasa atau proses penafsiran seperti pada analisis konstruktivis. Analisis wacana dalam paradigma ini menekankan pada konstelasi kekuatan yang terjadi pada proses produksi dan reproduksi makna. Individu tidak dianggap sebagai subyek yang netral yang bisa menafsirkan secara bebas sesuai dengan pikirannya, karena sangat berhubungan dan dipengaruhi oleh kekuatan sosial yang ada dalam masyarakat. Bahasa dalam pandangan kritis dipahami sebagai representasi yang berperan dalam membentuk subyek tertentu, tema-tema wacana tertentu, maupun strategi-strategi di dalamnya. Oleh karena itu, analisis wacana dipakai untuk membongkar kuasa yang ada dalam setiap proses bahasa: batasan-batasan apa yang diperkenankan menjadi wacana, perspektif yang mesti dipakai, topik apa yang dibicarakan. Wacana melihat bahasa selalu terlibat dalam hubungan kekuasan, terutama dalam pembentukan subyek, dan berbagai tindakan representasi yang terdapat dalam masyarakat (Eriyanto, 2012: 4-6).

Analisis Wacana Kritis (AWK) mencoba untuk membongkar yang salah atau tidak beres di masyarakat, seperti adanya ketidakadilan, ketaksetaraan, pembatasan kebebasan atau diskriminasi (Haryatmoko, 2016:vi). Agar AWK semakin tajam, orang perlu menganalisis pula hubungan dengan luar teks yang meliputi . Analisis ini membahas bagaimana unsur lain secara intertekstual terkait dengan teks; dan bagaimana suara-suara lain termuat dalam teks; akhirnya, bagaimana teks lain disinggung, diasumsikan, atau didialogkan. Intertekstualitas ini bisa tampak dalam dua bentuk: pertama, kehadiran unsur-unsur dari teks lain dalam suatu teks yang bisa berupa kutipan, acuan, atau isi; kedua, dalam laporan pembicaraan, tulisan atau pikiran, bukan hanya kutipan yang kita jumpai, namun bisa juga ringkasan. Maka teks selalu memiliki asumsi (Haryatmoko, 2016:18).

Analisis Wacana Kritis Model Norman Fairclough didasarkan pada sebuah pertanyaan, yaitu bagaimana menghubungkan teks yang mikro dengan konteks masyarakat yang makro. Titik utamanya adalah melihat bahasa sebagai praktik kekuasaan. Oleh karena itu, Analisis Wacana Kritis Model Norman Fairclough harus dipusatkan pada bagaimana bahasa itu terbentuk dan dibentuk dari relasi sosial dan konteks sosial tertentu. 
Model analisis Norman Fairclough sering juga disebut sebagai model perubahan sosial. Dalam bukunya, Eriyanto (2012) menyampaikan bagaimana Fairclough membagi analisis wacana dalam tiga dimensi: teks, discourse practice, dan sociocultural practice. Teks dianalisis secara linguistik, dengan melihat kosakata, semantik, dan tata kalimat. la juga memasukkan koherensi dan kohesivitas, bagaimana antarkata atau kalimat tersebut digabung sehingga membentuk pengertian. Pertama, ideasional yang merujuk pada representasi tertentu yang ingin ditampilkan dalam teks, yang umumnya membawa muatan ideologis tertentu. Kedua, relasi, merujuk pada analisis bagaimana konstruksi hubungan di antara wartawan dengan pembaca. Ketiga, identitas, merujuk pada konstruksi tertentu dari identitas wartawan dan pembaca, serta bagaimana personal dan identitas ini hendak ditampilkan.

Discourse practice merupakan dimensi yang berhubungan dengan proses produksi dan konsumsi teks. Sebuah teks berita pada dasarnya dihasilkan lewat proses produksi teks yang berbeda, seperti bagaimana pola kerja, bagan kerja, dan rutinitas dalam menghasilkan berita. Media yang satu mungkin sekali mempunyai pola kerja dan kebiasaan yang berbeda dibandingkan dengan media lain. Proses konsumsi teks bisa jadi juga berbeda dalam konteks sosial yang berbeda pula. Konsumsi juga bisa dihasilkan secara personal ketika seseorang mengonsumsi teks (seperti ketika menikmati puisi) atau secara kolektif (peraturan perundangundangan atau sebagainya). Sementara dalam distribusi teks, tergantung pada pola dan jenis teks dan bagaimana sifat institusi yang melekat dalam teks tersebut.

Sedangkan sociocultural practice adalah dimensi yang berhubungan dengan konteks di luar teks. Konteks di sini memasukkan banyak hal, seperti konteks situasi, lebih luas adalah konteks dari praktik institusi dari media sendiri dalam hubungannya dengan masyarakat atau budaya dan politik tertentu. Misalnya politik media, ekonomi media, atau budaya media tertentu yang berpengaruh terhadap berita yang dihasilkannya (Eriyanto, 2012: 286-288).

Ketiga dimensi yang dikemukakan oleh Norman Fairclough biasanya dirumuskan dalam suatu gi

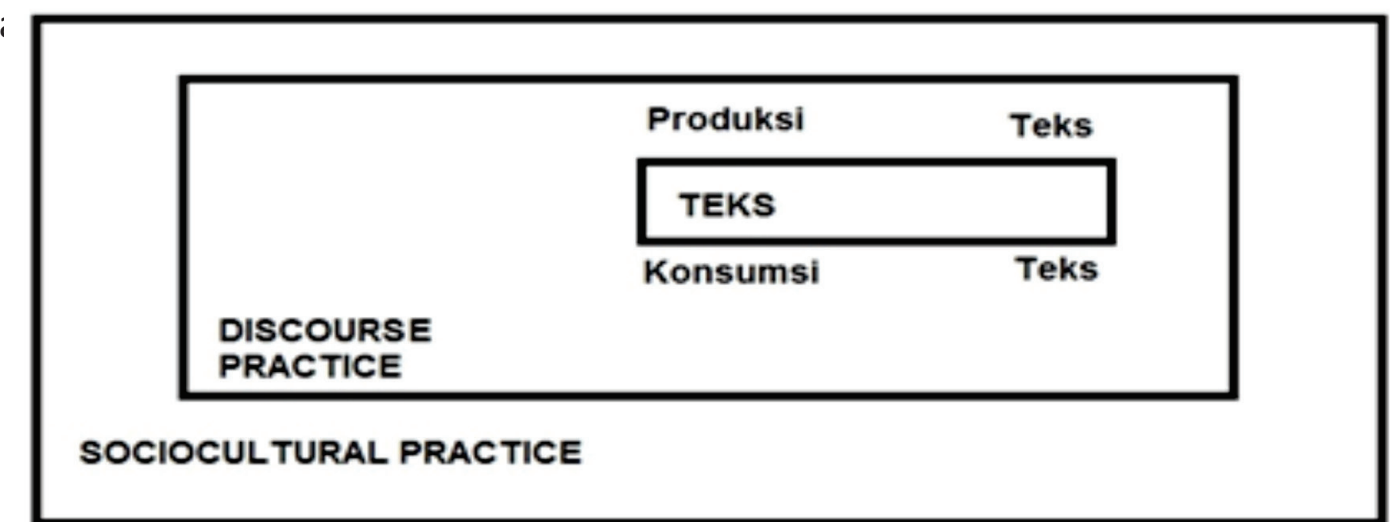

Gambar 2.1 Dimensi Analisis Norman Fairclough

Sumber : Eriyanto (2012 : 288) 
Fairclough menawarkan empat langkah metode AWK (N.Fairclough, 2010:235). Pertama, memfokuskan pada suatu 'ketidakberesan sosial', dalam aspek semiotiknya. Ketidakberesan sosial dipahami sebagai aspek-aspek sistem sosial, bentuk dan tatanan yang merugikan atau merusak kesejahteraan bersama, yang bisa diperbaiki meski harus melalui perubahan-perubahan radikal dari sistem. Ketidakberesan sosial itu meliputi kemiskinan, ketidasetaraan, diskriminasi, kurangnya kebebasan atau rasisme (Haryatmoko, 2016:20). Kedua, mengidentifikasi hambatan-hambatan untuk menangani 'ketidakberesan sosial' itu. Pada tahap ini, pendekatan terhadap ketidakberesan sosial ditempuh dengan cara tidak langsung, yaitu dengan menanyakan cara bagaimana kehidupan sosial diorganisir dan distruktur sehingga mencegahnya dari upaya menanganinya. Hal ini butuh analisis tatanan sosial dan satu titik masuk ke analisis menjadi semiotik. Maka perlu menyeleksi dan menganalisis teksteks yang relevan dan membahas hubungan dialektik antara semiosis dan unsur-unsur sosial lainnya (Haryatmoko, 2016:21).

Ketiga, mempertimbangkan apakah tatanan sosial itu 'membutuhkan' ketidakberesan sosial tersebut. Apakah 'ketidakberesan sosial' melekat pada tatanan sosial, apakah dapat ditangani dalam sistem tersebut, atau hanya bisa ditangani bila diubah. Ini adalah cara menghubungkan antara 'yang faktual' dan 'yang seharusnya': jika suatu tatanan sosial dapat ditunjukkan untuk menghasilkan 'ketidakberesan sosial' yang besar, maka menjadi alasan untuk memikirkan agar diubahnya. Hal ini terkait dengan masalah ideologi: wacana selalu ideologis sejauh menyumbang untuk mendukung hubungan kekuasaan dan dominasi tertentu (Haryatmoko, 2016:21). Keempat, mengidentifikasi cara-cara yang mungkin untuk mengatasi hambatan-hambatan itu. Analisis pada tahap ini mau mengidentifikasi kemungkinankemungkinan dalam proses sosial yang ada untuk mengatasi hambatan-hambatan menangani 'ketidakberesan sosial'. (Haryatmoko, 2016:21-22).

\section{Metodologi Penelitian}

Metode yang digunakan dalam penelitian ini adalah Analisis Wacana Kritis Norman Fairclough. Peneliti menilai model ini adalah metode yang tepat untuk menganalisis wacana yang telah dipilih, serta mengkaji konteks sosial yang tersembunyi dibelakangnya. Dengan demikian, penelitian ini akan memfokuskan pada aspek penggunaan bahasa dan konteks-konteks yang terkait dengan aspek tersebut.

Analisis wacana kritis adalah bagian dari analisis isi kualitatif. Metode penelitian yang menggunakan teks sebagai bahan dasar analisisnya. Analisis isi model ini mengemukakan gagasan penulis yang termanifestasi maupun yang tidak tertera. Makanya metode ini menjembatani isi media, membandingkan media, menjelaskan kecenderungan dalam konten komunikasi (Weber, 1990:9). Karena fokus pada teks, analisis isi kualitatif sangat akrab dengan komunikasi. 
Adapun teks berita yang terpilih menjadi objek penelitian adalah teks berita pasca sidang putusan praperadilan kasus korupsi e-KTP Setya Novanto di Tribunnews.com tanggal 30 September 2017 berdasarkan headline yang menonjolkan KPK. Dari 24 teks berita yang diproduksi oleh Tribunnews.com tanggal 30 September 2017, ada enam teks berita yang terpilih sebagai objek penelitian.

Ada dua tahapan analisis data yang dilakukan. Tahap pertama adalah pemahaman teks dan konteks. Ada lima langkah yang dijadikan acuan. Pertama, fokus kepada ketidakberesan sosial dalam aspek semiotikanya. Kedua, mengidentifikasi hambatan-hambatan untuk menangani aspek ketidakberesan sosial tersebut. Ketiga, mempertimbangkan apakah tatanan sosial membutuhkan ketidakberesan sosial itu. Keempat, mengidentifikasi cara-cara yang mungkin untuk mengatasi hambatan-hambatan tersebut. Kelima, melakukan refleksi secara kritis dari keempat poin tersebut.Dan tahap kedua adalah intertekstualitas. Yaitu bentuk kehadiran unsur-unsur dari teks lain dalam suatu teks yang bisa berupa kutipan, acuan atau isi. Bagaimana menunjukan suara-suara lain termuat dalam teks, termasuk bagaimana teks lain disinggung, diasumsikan, dibandingkan atau didialogkan.

\section{Hasil Penelitian dan Pembahasan}

\subsection{Fokus pada 'ketidakberesan sosial' dalam aspek semiotiknya}

Ketidakberesan sosial dipahami sebagai aspek-aspek sistem sosial, bentuk dan tatanan yang merugikan atau merusak kesejahteraan bersama, yang bisa diperbaiki meski harus melalui perubahan-perubahan radikal dari sistem. Ketidakberesan sosial itu meliputi kemiskinan, ketidasetaraan, diskriminasi, kurangnya kebebasan atau rasisme (Haryatmoko, 2016:20).

Dari enam berita yang dijadikan basis wacana dan dianalisis, semua menunjukkan satu hal. Bahwa Tribunnews.com meletakkan KPK sebagai pihak yang salah. Setnov yang benar. Diksi-diksi yang dipakai oleh media online ini menunjukan bahwa KPK tidak kredibel; bersalah; ceroboh, dan terbuiru-buru. Singkat kata KPK tidak memiliki kompetensi untuk menangani kasus Setnov.

Pertanyaannya adalah ada apa di balik berita Tribunnews.com yang menyalahkan dan menyudutkan posisi KPK? Terlihat bagan di bawah bagaimana redaksi Tribunnews.com meletakkan dan membingkai posisi KPK. Penggunaan metafora seperti blunder, premateur, pengkondisian, penzaliman, pencitraan, kontraproduktif, pukulan telak menunjukan KPK sedang dibidik oleh Tribunnews.com.

Posisi Tribunnews.com yang berlawanan dengan arus utama suara publik menunjukkan satu hal. Bahwa Tribunnews.com sedang mencari positioning dalam ranah pertarungan antarmedia online yang kian sengit setiap saat. Selama ini nyaris semua media dan elemen masyarakat yang mengaku prodemokrasi dan pemberantasan korupsi berada di belakang KPK. Right and wrong KPK is the best. Posisi berlawanan dengan arus besar suara publik ini yang kini 
ditempati Tribunnews.com. Tidak ada saingan dalam posisi ini. Dengan demikian, daya tawar Tribunnews.com menjadi unggul karena tidak memiliki pesaing. Dengan demikian kue iklan pun menjadi hak media online grup Kompas ini. Bandingkan jika Tribunnews.com bersama arus besar suara publik. la harus bersaing dalam isu ini. Puluhan bahkan ratusan ribu situs yang membela KPK. Dari sudut bisnis ini tidak menarik. Sebaliknya, Tribunnews.com cerdas membidik pasar dan pembaca. la membidik sisi pasar yang tidak tergarap oleh media online yang lain.

Tabel 2

Konstruksi Wacana

\begin{tabular}{|c|c|c|}
\hline \multicolumn{2}{|c|}{ Nama Media } & Tribunnews.com \\
\hline \multicolumn{2}{|c|}{ Edisi } & Sabtu, 30 September 2017 \\
\hline \multicolumn{2}{|c|}{ Konstruksi Wacana } \\
\hline No & KPK dan Konstruksi Media Online \\
\hline 1 & Kosa Kata & Keterangan \\
\hline 2 & Istilah & $\begin{array}{c}\text { KPK keok, KPK kalah, Kekalahan } \\
\text { keenam, KPK beropini, pelemahan } \\
\text { KPK, KPK khawatir, tampak ceroboh, } \\
\text { Terlalu terburu-buru, belum didukung } \\
\text { fakta-fakta }\end{array}$ \\
\hline 3 & Metafora & $\begin{array}{c}\text { Blunder, premateur, pengkondisian, } \\
\text { penzaliman, pencitraan, } \\
\text { kontraproduktif, pukulan telak }\end{array}$ \\
\hline 4 & Struktur Teks & $\begin{array}{c}\text { Dari awal hingga akhir membangun } \\
\text { susunan logika yang menyudutkan } \\
\text { KPK. Menyudutkan KPK; Melawan } \\
\text { opini publik tentang KPK hebat, } \\
\text { untouchable dan superpody }\end{array}$ \\
\hline & & $\begin{array}{c}\text { Tidak ada aspek positif atau apresiasi } \\
\text { terhadap kinerja KPK }\end{array}$ \\
\hline
\end{tabular}

Sumber : Hasil penelitian tahun 2018

\subsection{Mengidentifikasi hambatan-hambatan untuk menangani 'ketidakberesan sosial' tersebut}

Pada tahap ini, pendekatan terhadap ketidakberesan sosial ditempuh dengan cara tidak langsung, yaitu dengan menanyakan cara bagaimana kehidupan sosial diorganisir dan distruktur sehingga mencegahnya dari upaya menanganinya. Hal ini butuh analisis tatanan sosial dan satu titik masuk ke analisis menjadi semiotik. Maka perlu menyeleksi dan menganalisis teksteks yang relevan dan membahas hubungan dialektik antara semiosis dan unsur-unsur sosial lainnya (Haryatmoko, 2016:21). 
Dari enam berita yang dijadikan basis wacana dan dianalisis, semua menunjukkan bahwa Tribunnews.com menempatkan KPK sebagai lembaga yang dibentuk dan bertujuan untuk memberantas korupsi. la berdiri karena kinerja penegakkan hukum, khususnya pemberantasan korupsi oleh kepolisian dan kejaksaan mengecewakan. Sebagai kejahatan yang termasuk kategori ordinary crime, korupsi harus dipangkas. Dan ini tidak bisa dilakukan oleh kejaksaan dan kepolisaan yang 'berlumuran dosa korupsi' pun kesalahan korupsi yang tidak pernah tuntas.

Di sisi lain, KPK sesungguhnya dibentuk oleh institusi politik bersama DPR dan Presiden berdasarkan Undang-Undang. Artinya, KPK lebih merupakan hasil kompromi politik daripada tujuan mulia memberantas korupsi. DPR yang paling banyak dibidik KPK 'menyesal' membentuk KPK. Mereka pun ingin membubarkannya. Tidak terhitung statement, langkah, dan cara DPR membubarkan KPK. Terakhir dengan pansus hak angket

Munculnya hak angket dan rekomendasinya dari DPR harus dibaca sebagai bagian perlawanan terhadap (citra positif) KPK. Beberapa rekomendasi untuk perbaikan KPK versi DPR adalah :

\section{Aspek Kelembagaan}

1. Meminta presiden menyempurnakan struktur organisasi KPK sesuai dengan Undang-Undang Nomor 30 Tahun 2002 tentang KPK yang meliputi koordinasi, supervisi, penindakan, pencegahan, dan monitoring.

2. Meminta KPK meningkatkan kerja sama dengan lembaga penegak hukum dan lembaga lain, seperti Pusat Pelaporan Analisis dan Transaksi Keuangan serta perbankan, agar pemberantasan korupsi dapat dilakukan secara optimal, terintegrasi, dan bersinergi.

3. Meminta presiden serta KPK membentuk lembaga pengawas independen yang beranggotakan unsur internal KPK dan tokoh masyarakat yang berintegritas melalui peraturan presiden.

\section{Aspek Kewenangan}

1. Meminta KPK membangun jaringan kerja yang kuat dalam menjalankan tugas koordinasi dengan kepolisian dan kejaksaan.

2. Meminta KPK memperhatikan prinsip hak asasi manusia serta mengacu pada hukum acara pidana yang berlaku dalam menjalankan tugas penyelidikan, penyidikan, dan penuntutan.

3. Meminta KPK membangun sistem pencegahan dan monitoring yang sistemik agar dapat mencegah korupsi berulang serta penyalahgunaan keuangan negara.

\section{Aspek Anggaran}

1. Meminta KPK meningkatkan dan memperbaiki tata kelola anggarannya sesuai dengan rekomendasi Badan Pemeriksa Keuangan. 
2. Meminta KPK mengoptimalkan penggunaan anggaran dalam fungsi pencegahan sehingga dapat memberi pemahaman yang lebih komprehensif kepada masyarakat.

\section{Aspek Tata Kelola Sumber Daya Manusia}

1. Meminta KPK memperbaiki tata kelola sumber daya manusia dengan memperhatikan peraturan perundang-undangan di bidang kepegawaian.

2. Meminta KPK semakin transparan dan terukur dalam proses pengangkatan, promosi, mutasi, rotasi, serta pemberhentian sumber daya manusia KPK dengan mengacu pada Undang-Undang Aparatur Sipil Negara, UU Kepolisian RI, dan UU Kejaksaan RI (https://nasional.tempo.co/read/1056595/berikut-ini-10 rekomendasi-pansushak-angket-untuk-kpk, diakses terakhir 24 Maret 2018 pukul 05.26 WIB)

Sebagaimana diketahui, kinerja KPK selalu dielu-elukan publik. la menjadi media darling. Kasus Cicak versus Buaya, pembelaan publik dan negara terhadap Abraham Samad dan Bambang Widjoyanto misalnya, dan banyak lagi kasus lainnya menunjukan bahwa KPK dibela publik. Apapun alasannya. KPK menjadi mitos yang tidak boleh salah. Mitos lembaga yang bisa memberantas korupsi padahal omong besar. Kasus Setnov dalam berita ini menunjukan bahwa KPK hanyalah macan ompong. la ada jika dibela publik. KPK tidak lagi kredibel dalam menjalankan fungsi dan kewenangannya dalam memberantas korupsi di negeri ini

Kini kedudukan KPK mulai goyah. Jika sebelumnya dalam beragam survei KPK selalu berada di peringkat pertama, kini mulai bergeser. Berdasarkan hasil survei Lembaga Survei Indonesia (LSI) yang lain menyebutkan bahwa KPK berada pada urutan keempat terkait dengan opini masyarakat mengenai seberapa bersih lembaga pemerintah dari korupsi. LSI mencatat lembaga pemerintah yang dinilai paling bersih dari korupsi adalah TNI (57,2 persen), Presiden (51 persen), Polri (39,3 persen), KPK (38,5 persen), dan Bank Indonesia (38,2 persen) (https:// nasional.tempo.co/read/375990/survei-warga-anggap-polisi-lebih-bersih-dari-kpk. Diakses terakhir 24 Maret 2018 pukul 05.18 Wib).

Tingkat kepercayaan tersebut, ternyata sejalan dengan tingkat kepuasan publik. Dalam pemaparannya, Direktur Eksekutif Poltracking Indonesia, Hanta Yudha mengatakan bahwa TNI lembaga yang dinilai kinerjanya paling memuaskan. Dalam penilaian kinerja institusi demokrasi dan penegakan hukum, sebanyak 69 persen publik mengaku puas terhadap kinerja TNI. Diikuti kepuasan terhadap kinerja presiden 64 persen, dan KPK 59 persen. Kinerja DPR masih bertahan di posisi buncit. Sebab, secara keseluruhan hanya 34 persen publik yang mengaku puas atas kinerja wakil rakyat (https://poltracking.com/survei-poltracking-kinerja-tni-di-atas-kpk-dprterburuk.html. Diakses terakhir 24 Maret 2018 pukul 05.22 WIB.

\subsection{Mengidentifikasi apakah tatanan sosial "membutuhkan" ketidakberesan sosial}

Apakah 'ketidakberesan sosial' melekat pada tatanan sosial, apakah dapat ditangani dalam sistem tersebut, atau hanya bisa ditangani bila diubah. Ini adalah cara menghubungkan 
antara 'yang faktual' dan 'yang seharusnya': jika suatu tatanan sosial dapat ditunjukkan untuk menghasilkan 'ketidakberesan sosial' yang besar, maka menjadi alasan untuk memikirkan agar diubahnya. Hal ini terkait dengan masalah ideologi: wacana selalu ideologis sejauh menyumbang untuk mendukung hubungan kekuasaan dan dominasi tertentu (Haryatmoko, 2016:21).

Harus diakui hingga kini nama besar KPK dibutuhkan untuk 'pemberantasan korupsi.' Minimal ia menakut-nakuti pejabat negara yang suka korupsi. Kalau memberantas korupsi secara keseluruhan, itu sesuatu yang mustahil. Faktor pemberantasan korupsi bukan tanggung jawab KPK tetapi tugas semua elemen bangsa ini. Mulai dari Presiden hingga rakyat jelata. Ini perjuangan yang panjang dan membutuhkan kesabaran serta energi yang nyaris tak pernah pupus.

Meskipun sikap pesimistis terhadap kinerja KPK, hingga kini ketergantungan masyarakat dan publik kepada KPK tetap besar. Ini terjadi karena kinerja kepolisian dan kejaksaan dalam pemberantasan korupsi tidak juga membaik. Bahkan cenderung lepas tangan. Tidak pernah terdengar lagi kepolisian dan kejaksaan menggarap lahan pemberantasan korupsi.

Dengan demikian ketika diserang semua pihak, publik, media, dan elemen prodemokrasi berdiri menghadang pihak yang ingin meruntuhkan KPK. Walaupun KPK berada di posisi yang lemah dan salah. Di sinilah pencitraan KPK sebagai lembaga yang harus dibela berhasil. KPK berhasil membangun opini publik.

Citra berarti gambaran. la sesuatu yang abstrak. Secara lengkap citra dapat didefinisikan konstruksi atas representasi dan persepsi khalayak terhadap individu, kelompok atau lembaga yang terkait dengan kiprahnya di masyarakat. Sedangkan pencitraan berarti proses pembentukan citra melalui proses yang diterima oleh khalayak baik secara langsung maupun melalui media sosial atau media massa. Karena itulah citra berkaitan dengan empat hal. Yakni:

(1) representasi di mana citra merupakan cermin realitas;

(2) ideologi di mana citra menyembunyikan dan memberi gambaran yang salah tentang realitas:

(3) citra menyembunyikan bahwa tidak ada realitas, dan

(4) citra tidak memiliki sama sekali hubungan dengan realitas apapun.

Jika ditautkan dengan politik, citra politik bisa diartikan gambaran seseorang tentang politik. Dunia politik berkaitan dengan kekuasaan, otoritas, pengaruh, dan kerja sama, konflik, dan konsensus. Citra politik memiliki makna meski tidak menggambarkan sesuatu yang sebenarnya. Dengan demikian sesungguhnya pencitraan bukan gambaran sejati dari sosok yang dicitrakan. Apalagi pencitraan yang dihasilkan oleh media massa. Sebab berita yang diterima dan mempengaruhi khalayak bukan realitas yang sebenarnya. la menjadi realitas buatan atau realitas kedua atau realitas buatan. 
Dalam negara demokratis seperti di negeri kita, pencitraan sangat penting. Hal ini disebabkan adanya persaingan atau kompetisi dengan orang lain. Dalam demokrasi tidak penting suara siapa (kualitas) yang mendukung. Yang terpenting dan menentukan adalah suara mayoritas (kuantitatif). Dalam konteks ini, sosok calon di mata khalayak/pemilih menjadi faktor penentunya. Pemilih akan memberikan suaranya kepada yang dikenal, baik, dan membela kepentingannya. Oleh sebab itu, dalam dunia politik di negara demokratis/liberal yang terpenting dikenal publik, bukan moralitas pribadi atau kendaraan politik. Makanya, di negara negara demokratis seperti di negara kita popularitas yang dihasilkan oleh media massa merupakan faktor kunci meraih pencitraan.

Jika mengikuti definisi di atas bahwa pencitraan adalah proses pembentukan citra melalui proses yang diterima oleh khalayak baik secara langsung maupun melalui media sosial atau media massa, maka dalam perspektif ilmu komunikasi, ia berada dalam dapur komunikator. Oleh sebab itu, jika mengikuti pola komunikasi ala Lasswell, analisis yang digunakan adalah analisis kontrol atau analisis sumber. Dengan kata lain pencitraan adalah segala upaya yang dilakukan komunikator politik untuk memperoleh gambaran baik tentang dirinya. Upaya itu bisa dilakukan secara langsung maupun media massa dan media sosial.

Dalam dunia modern citra dibentuk melalui media massa. Dengan demikian konstruksi citra yang dibentuk oleh media massa tersebut menggelinding menjadi opini publik. Terbangunnya citra positif seseorang tidak bisa dilepaskan dari kemampuan berkomunikasi dan membangun relasi dengan media massa. Hubungan baik ini kemudian dicitrakan atau dipantulkan media massa ke benak khalayak. Karena terus diulang, pesan media tentang citra seseorang terbentuk di khalayak.

Ukuran yang paling kentara dari keberhasilan sebuah usaha politik pencitraan adalah terbangunnya opini publik yang positif tentang komunikator politik di benak khalayak. Anwar Arifin mendefinisikan opini publik sebagai pendapat yang sama dan dinyatakan oleh banyak orang yang diperoleh melalui diskusi intensif sebagai jawaban atas pertanyaan dan permasalahan yang menyangkut kepentingan umum. Ada tiga unsur dalam opini publik. Yaitu isu yang aktual dan menyakut kepentingan umum, yang disiarkan media, adanya sejumlah orang yang mendiskusikannya, dan pendapat itu diekspresikan melalui lisan, tulisan, dan gerak-gerik (Opini Publik, Gramata Publishing, Jakarta, 2010:11-13).

Sambil menyitir E. Rogers dan Shoumakers, Anwar Arifin (2011:91), menyatakan ada lima tahap terbangunnya opini publik yang disebabkan media massa. Yaitu, kesadaran, perhatian, evaluasi, coba-coba, dan adopsi. Kesadaran dan perhatian menjadi pintu utama masuknya pengaruh media yang kemudian membentuk opini publik.

Meskipun belum berhasil sepenuhnya KPK dinilai publik merupakan alat paling efektif memberantas korupsi. Oleh karena itu, publik menolak berbagai upaya untuk mengkerdilkan kewenangannya. Tercatat sejak dibentuk Desember 2003, KPK memenjarakan puluhan 
birokrat, politisi, dan swasta pelaku korupsi. Karena jejaknya melebihi kepolisian dan kejaksaan publik mengapresiasinya. Citra positif melekat di tubuhnya. Hasil jajak pendapat Kompas di 12 kota pekan lalu tetap memperlihatkan penilaian tersebut. Sebanyak 71,7 persen responden jajak pendapat memberi penilaian positif terhadap KPK. Makanya ketika muncul indikasi pelemahan KPK, publik bereaksi membelanya (https://www.kpk.go.id/id/halaman-utama/79berita/berita-media/294-publik-menolak-pelemahan-kpk. Diakses terakhir 24 Maret 2018 pukul $05.10 \mathrm{Wib})$.

\subsection{Mengidentifikasi cara-cara yang mungkin untuk mengatasi hambatan-hambatan tersebut}

Analisis pada tahap ini mau mengidentifikasi kemungkinan-kemungkinan dalam proses sosial yang ada untuk mengatasi hambatan-hambatan menangani 'ketidakberesan sosial'. (Haryatmoko, 2016:21-22). Secara historis KPK berdiri karena dorongan suara publik yang prihatin dengan pemberantasan korupsi yang dilakukan kepolisiaan dan kejaksaan. Publik menginginkan lembaga yang kredibel dan cenderung superbody dalam memberantas korupsi. Lembaga ini independen, otonom dan merupakan lembaga negara yang langsung di presiden.

Dalam perkembangan selanjutnya, pada 2004, arus besar suara publik itu mewujud dalam KPK ketika era Presiden Megawati Soekarnoputri. Mulai saat itu kiprah KPK banyak mendapat simpatik publik. Lewat operasi tangkap tangan atao OTT, KPK memberi harapan pada pemberantasan korupsi. Puluhan orang pejabat negara, mulai dari menteri, gubernur, bupati/walikota dan anggota dewan dijebloskan ke penjara karena korupsi. Mereka yang korupsi dan dahulu tidak tersentuh kini terpaksa meringkuk di hotel prodeo.

Tetapi seiring perkembangan waktu, KPK mulai tergerus oleh kepentingan politik. la menjadi alat kekuasaan. Kasus korupsi Anas Urbaningrum di era Presiden Susilo Bambang Yudhoyono adalah salah satunya. Kasus Cicak vs Buaya, dan penetapan tersangka Ketua KPK Abraham Samad dan Wakil Ketua Bambang Widjoyanto adalah bentuk lain pertarungan politik KPK dengan institusi lain. Ini tentu sebuah preseden yang tidak baik. Lembaga penegakan hukum bermain politik. Pertarungan dengan kepolisian dan kejaksan pun berkembang menjadi rivalitas yang membenturkan antar lembaga negara. Karena sebagian penyidik KPK berasal dari kejaksaan dan kepolisian.

Oleh sebab itu, salah satu pekerjaan rumah KPK adalah memperbaiki sistem rekruitmen komisioner dan penyidik. Mereka harus independen. Tidak lagi berasal dari kepolisian dan kejaksaan. Untuk inilah diakui atau tidak memang harus revisi terbatas UU KPK sehingga KPK harus lebih independen dalam berbagai elemennya. Dengan demikian, KPK akan kredibel di masa mendatang. Tidak ada lagi gerakan pelemahan KPK seperti yang dilakukan DPR beberapa waktu silam. 
Tabel 3

\section{Element CDA Norman Fairclough}

\begin{tabular}{|c|l|l|}
\hline \multicolumn{3}{|c|}{ Konstruksi KPK dalam Media Online } \\
\hline No & Element CDA Norman Fairclough & Keterangan \\
\hline 1 & $\begin{array}{l}\text { Memfokuskan pada ketidakber- } \\
\text { esan sosial dalam aspek semiotika }\end{array}$ & $\begin{array}{l}\text { Pilihan kata, diksi, kalimat dan } \\
\text { judul berita menunjukan posisi } \\
\text { tribunnews.com yang menjelek- } \\
\text { kan KPK. la berseberangan den- } \\
\text { gan suara publik yang membela } \\
\text { KPK }\end{array}$ \\
\hline 2 & $\begin{array}{l}\text { Identifikasi hambatan-hambatan } \\
\text { untuk menangani ketidakberesan } \\
\text { sosial tersebut }\end{array}$ & $\begin{array}{l}\text { Kinerja penegakkan hukum oleh } \\
\text { kepolisiaan dan kejaksaan masih } \\
\text { mengecewakan } \\
\text { KPK sebagai kompromi politik } \\
\text { Dibentuk oleh institusi politik }\end{array}$ \\
\hline 3 & $\begin{array}{l}\text { Apakah tatanan sosial membu- } \\
\text { tuhkan ketidakberesan sosial } \\
\text { tersebut }\end{array}$ & $\begin{array}{l}\text { Nama besar KPK dibutuhkan un- } \\
\text { tuk 'pemberantasan korupsi' } \\
\text { KPK diserang semua pihak } \\
\text { KPK dilemahkan } \\
\text { KPK harus dibela }\end{array}$ \\
\hline 4 & $\begin{array}{l}\text { Mengidentifikasi cara-cara yang } \\
\text { mungkin untuk mengatasi ham- } \\
\text { batan tersebut }\end{array}$ & $\begin{array}{l}\text { Arus besar suara publik } \\
\text { Memperbaiki rekruitmen komi- } \\
\text { soner dan penyidik independen } \\
\text { Revisi terbatas UU KPK }\end{array}$ \\
\hline
\end{tabular}

Sumber : Hasil penelitian Tahun 2018

\section{Simpulan dan Saran}

Dari enam berita yang dijadikan basis wacana dan analisis, Tribunnews.com meletakkan KPK sebagai pihak yang salah. Setnov yang benar. Diksi-diksi yang dipakai oleh media online ini menunjukan bahwa KPK tidak kredibel; bersalah; kurang cermat, keliru, ceroboh, dan terburu-buru. KPK dikonstruksikan tidak memiliki kompetensi untuk menangani kasus Setnov. Tribunnews.com mengarahkan pandangan khalayak untuk menyudutkan KPK. Pihak Setnov diposisikan sebagai pihak yang belum tentu bersalah dalam kasus e-KTP. Tribunnews. com lebih banyak membeberkan informasi yang menjadi penyebab KPK gagal dalam sidang praperadilan Setnov. Tribunnews.com menggiring khalayaknya untuk menyetujui keputusan hakim tunggal Cepi Iskandar yang memenangkan Setnov.

Sebagai saran, penelitian ini diharapkan dapat memberi tambahan pengetahuan kepada pembaca bahwa tentang tak ada peristiwa/realitas/fakta yang ditampilkan apa adanya, melainkan peristiwa/realitas/fakta tersebut telah dikonstruksi sedemikian rupa oleh media 
bersangkutan. Selanjutnya, perbaikan sistem KPK secara menyeluruh akan mengembalikan KPK kepada marwahnya sebagai lembaga independen, otonom, dan bergigi dalam pemberantasan korupsi di negeri ini.

\section{Daftar Pustaka}

Arifin, Anwar. 2006. Pencitraan dalam Politik. Jakarta: Pustaka Indonesia. . 2011. Opini Publik, Depok: Gramata.

Eriyanto. 2012. Analisis Framing: Konstruksi, Ideologi dan Politik Media. Yogyakarta: PT LkiS Printing Cemerlang.

Fairclough, N. 2010. Critical Discourse Analysis: The Critical Study of Language. Edinburg: Longman.

Hamad, Ibnu. 2014. Konstruksi Realitas Politik dalam Media Massa: Sebuah Studi Critical Discourse Analysis terhadap Berita-berita Politik, ed. 1. Jakarta: Granit.

Haryatmoko. 2016. Critical Discourse Analysis (Analisis Wacana Kritis): Landasan Teori, Metodologi dan Penerapan, Jakarta: PT Raja Grafindo Persada.

\section{Sumber online :}

http://www.islamcendekia.com/2014/04/pengertian-korupsi-menurut-uu-tipikor.html https://poltracking.com/survei-poltracking-kinerja-tni-di-atas-kpk-dpr-terburuk.html. Diakses terakhir 24 Maret 2018 pukul 05.22 Wib

https://www.kpk.go.id/id/halaman-utama/79-berita/berita-media/294-publik-menolakpelemahan-kpk. Diakses terakhir 24 Maret 2018 pukul 05.10 Wib

https://nasional.tempo.co/read/375990/survei-warga-anggap-polisi-lebih-bersih-dari-kpk. Diakses terakhir 24 Maret 2018 pukul 05.18 Wib

https://nasional.tempo.co/read/1056595/berikut-ini-10 rekomendasi-pansus-hak-angketuntuk-kpk, diakses terakhir 24 Maret 2018 pukul 05.26 WIB 